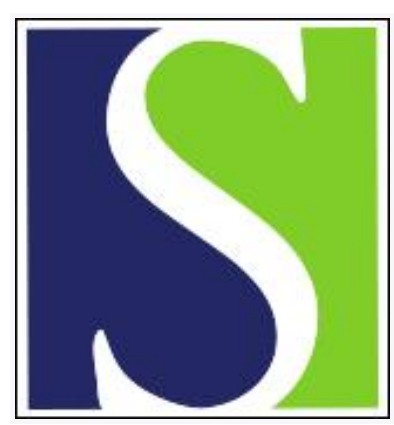

Scand J Work Environ Health 1978;4(4):275-283

https://doi.org/10.5271/sjweh.2698

Issue date: Dec 1978

Radiographic and physiological findings in patients with asbestosis.

by Zitting A, Huuskonen MS, Alanko K, Mattsson T

Key terms: asbestosis; bilateral fibrosis; patient; physiological finding; pleural change; radiographic appearance; radiographic finding; restrictive impairment

This article in PubMed: www.ncbi.nlm.nih.gov/pubmed/734388

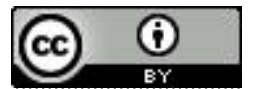




\title{
Radiographic and physiological findings in patients with asbestosis
}

\author{
by ANDERS ZITTING, M.D., ${ }^{1}$ MATTI S. HUUSKONEN, M.D., ${ }^{1}$ \\ KARI ALANKO, M.D., ${ }^{2}$ and TOR MATTSSON, M.D. ${ }^{1}$
}

\begin{abstract}
ZITTING, A., HUUSKONEN, M. S., ALANKO, K. and MATTSSON, T. Radiographic and physiological findings in patients with asbestosis. Scand. $j$. work environ. \& health 4 (1978) 275-283. Radiographic and respiratory functional findings are reported for a series of 133 Finnish patients with asbestosis. Of these patients, 65 $(49 \%$ ) were found to have radiographically mild diffuse pulmonary fibrosis (profusion $0 / 1,1 / 0$ or $1 / 1), 48(36 \%)$ moderate fibrosis $(1 / 2,2 / 1$ or $2 / 2)$ and $20(15 \%)$ diffuse fibrosis in an advanced stage (2/3 or more). The type of fibrosis was mostly irregular $(110=83 \%)$. Fibrosis was typically the most advanced in the lower zones of the lungs. Of the 133 patients, $88(66 \%)$ showed pleural changes and $78(59 \%)$ pleural calcifications. The more severe the fibrosis, as seen in the radiographs, the greater the decrease in vital capacity (VC) and expiratory volume in $1 \mathrm{~s}\left(\mathrm{FEV}_{1.0}\right)$. Transfer factor was generally impaired only in advanced cases of asbestosis (fibrosis $2 / 3$ or more). In general, obstruction was not observed in this series. Pleural changes seemed to decrease $\mathrm{VC}$ and $\mathrm{FEV}_{1.0}$ when the fibrosis was mild $(0 / 1,1 / 0$ or $1 / 1)$. They had no effect on diffusion capacity $\left(\mathrm{T}_{\mathrm{L}_{\mathrm{co}}}\right)$.
\end{abstract}

Key words: asbestosis, bilateral fibrosis, pleural changes, radiographic appearances, restrictive impairment.

Asbestosis, a disease of asbestos workers, is characterized by progressive pulmonary fibrosis and is, in some cases, associated with pleural thickening and calcification. The distribution of both pulmonary and pleural lesions is usually basal.

The abnormalities of pulmonary function in patients with asbestosis have already been described well $(17,21)$. Bader et al. (1) concluded that the most sensitive index of progression of the disease is

\footnotetext{
1 Department of Occupational Medicine, Institute of Occupational Health, Helsinki, Finland.

2 Päijät-Hämeen Keskussairaala, Lahti, Finland.

Reprint requests to: Dr. T. Mattsson, Institute of Occupational Health, Haartmaninkatu 1, SF-00290 Helsinki 29, Finland.
}

the change in vital capacity, which correlates well with radiographic changes. Opinions differ, however, concerning the value of the gas transfer factor in the diagnosis of asbestosis $(14,22)$. The correlations between the radiographic findings and lung function of asbestos workers have varied $(1,2,14,17,21,22)$.

Asbestosis is regarded as a difficult disease to diagnose. The problem is to identify early changes that are barely outside normal limits and to distinguish cases, even when advanced, from the many other conditions that can cause similar radiographic changes $(6,9,18)$.

The aim of the present study was to determine the radiographic and physiological findings of 133 asbestosis patients, to compare these findings, and to analyze the radiographic progression of asbestosis. 
Table 1. Characteristics of the subjects at the time of the reexamination.

\begin{tabular}{|c|c|c|c|c|c|c|}
\hline \multirow{2}{*}{ Occupation } & \multicolumn{2}{|c|}{$\operatorname{Sex}$} & \multicolumn{4}{|c|}{ Age at time of reexamination (years) } \\
\hline & Males & Females & $\leq 39$ & $40-49$ & $50-59$ & $\geq 60$ \\
\hline $\begin{array}{l}\text { Insulators } \\
\mathrm{N}=55\end{array}$ & 54 & 1 & 1 & ${ }_{\text {mean }} 155.6$ & 19 & 20 \\
\hline $\begin{array}{l}\text { Workers in } \\
\text { asbestos } \\
\text { cement } \\
\text { product } \\
\text { factory } \\
\mathrm{N}=32\end{array}$ & 16 & 16 & 0 & mean 24.0 & 7 & 23 \\
\hline $\begin{array}{l}\text { Workers in } \\
\text { asbestos } \\
\text { quarry } \\
\mathrm{N}=29\end{array}$ & 27 & 2 & 1 & $\begin{array}{c}9 \\
\text { mean } 52.9\end{array}$ & 13 & 6 \\
\hline $\begin{array}{l}\text { Asbestos } \\
\text { sprayers } \\
\mathrm{N}=8\end{array}$ & 8 & 0 & 5 & $\operatorname{mean}^{1} 41.0$ & 2 & 0 \\
\hline $\begin{array}{l}\text { Others } \\
N=9\end{array}$ & 8 & 1 & 0 & ${ }_{\text {mean }}^{2} 57.3$ & 2 & 5 \\
\hline $\begin{array}{l}\text { Total } \\
\mathrm{N}=133\end{array}$ & 113 & 20 & 7 & $\begin{array}{c}29 \\
\text { mean } 56.3\end{array}$ & 43 & 54 \\
\hline
\end{tabular}

\section{SUBJECTS AND METHODS}

Between 1964 and 1976, 229 cases of asbestosis were reported to the Occupational Disease Register in Finland. Of these cases $202(88 \%)$ had been diagnosed at the Institute of Occupational Health with the use of the following criteria:

(a) a confirmed history of occupational exposure to asbestos dust and

(b) a positive radiographic finding of fibrosis of the lungs.

Additional supporting features included: dyspnea on physical effort, persistent basal crepitations, clubbing of fingers, and a reduction in vital capacity, forced expiratory volume in $1 \mathrm{~s}$, and the single-breath carbon-monoxide transfer factor. These were not, however, used as essential diagnostic criteria.

In 1976 the 140 living asbestosis patients of those diagnosed at the Institute were asked to attend a reexamination between November 1976 and March 1977. A total of $133(95 \%)$ did so.

The present study deals with these 133 patients. Detailed information concerning work conditions with regard to asbestos exposure and other data were available (tables 1, 2 and 3).

The reexamination consisted of a radiographic examination, lung function tests, and a clinical examination.

The radiographic examination included one lateral and two full-size postero-anterior chest films. One of the postero-anterior radiographs was taken with a kilovoltage of 125 and the other with $70-80$ $\mathrm{kV}$. The kilovoltage of the lateral film was 125 . The mAs value was adjusted to obtain films of a suitable shade. (Most films were taken with an automatic exposure control.) The radiographic technique used at the time of diagnosis had been similar. The radiographs taken both at the time of diagnosis and at the reexamination were analyzed according to the ILO U/C International Classification of Radiographs of Pneumoconioses (extended classification) (10). They were examined by the same three persons, two radiologists and a specialist in occupational medicine at the Institute of Occupational Health.

Vital capacity (VC) and forced expiratory volume in $1 \mathrm{~s}\left(\mathrm{FEV}_{1.0}\right)$ were analyzed from flow volume curves registered with 
Table 2. Year of entry and age at entry into asbestos work.

\begin{tabular}{|c|c|c|c|c|c|c|c|c|c|}
\hline \multirow{2}{*}{ Occupation } & \multicolumn{5}{|c|}{ Year of entry } & \multicolumn{4}{|c|}{ Age at entery (years) } \\
\hline & $\leq 1929$ & $\begin{array}{c}1930- \\
1939\end{array}$ & $\begin{array}{r}1940- \\
1949\end{array}$ & $\begin{array}{c}1950- \\
1959\end{array}$ & $\geq 1960$ & $\leq 19$ & $20-29$ & $30-39$ & $\geq 40$ \\
\hline $\begin{array}{l}\text { Insulators } \\
\mathrm{N}=55\end{array}$ & 5 & 10 & $(1923-1971$ & 1) 18 & 2 & 19 & $\begin{array}{l}22 \\
\text { mean }\end{array}$ & $\begin{array}{r}9 \\
24.9\end{array}$ & 5 \\
\hline $\begin{array}{l}\text { Workers in } \\
\text { asbestos } \\
\text { cement } \\
\text { product } \\
\text { factory } \\
\mathrm{N}=32\end{array}$ & 1 & 8 & $(1928-196$ & 6) & 2 & 1 & $\begin{array}{l}11 \\
\text { mean }\end{array}$ & $\begin{array}{r}14 \\
32.4\end{array}$ & 6 \\
\hline $\begin{array}{l}\text { Workers in } \\
\text { asbestos } \\
\text { quarry } \\
\mathrm{N}=29\end{array}$ & 一 & 6 & ${ }_{(1931--196}^{13}$ & 5) 8 & 2 & 9 & $\begin{array}{l}16 \\
\text { mean }\end{array}$ & $\begin{array}{r}4 \\
22.8\end{array}$ & 一 \\
\hline $\begin{array}{l}\text { Asbestos } \\
\text { sprayers } \\
N=8\end{array}$ & - & - & $(1952-196$ & ) & 7 & - & $\begin{array}{l}6 \\
\text { mean }\end{array}$ & $\begin{array}{r}2 \\
25.6\end{array}$ & 一 \\
\hline $\begin{array}{l}\text { Others } \\
\mathrm{N}=9\end{array}$ & - & 1 & $(1938-196$ & 4 & 3 & - & $\begin{array}{l}3 \\
\text { mean }\end{array}$ & $\begin{array}{r}3 \\
39.7\end{array}$ & 3 \\
\hline $\begin{array}{l}\text { Total } \\
N=133\end{array}$ & 6 & 25 & $(1923-197$ & 37 & 16 & 29 & $\begin{array}{l}58 \\
\text { mean }\end{array}$ & $\begin{array}{c}32 \\
27.3\end{array}$ & 14 \\
\hline
\end{tabular}

Table 3. Length of asbestos exposure and smoking habits.

\begin{tabular}{|c|c|c|c|c|c|c|c|c|c|c|}
\hline \multirow{3}{*}{ Occupation } & \multicolumn{4}{|c|}{ Exposure years } & \multicolumn{6}{|c|}{ Smoking habits } \\
\hline & \multirow{2}{*}{$\leq 9$} & \multirow{2}{*}{$10-19$} & \multirow[t]{2}{*}{$20-29$} & \multirow{2}{*}{$\geq 30$} & \multicolumn{2}{|c|}{ Nonsmokers } & \multicolumn{2}{|c|}{ Exsmokers } & \multicolumn{2}{|c|}{ Smokers } \\
\hline & & & & & $\mathrm{N}$ & $\%$ & $\mathrm{~N}$ & $\%$ & $\mathrm{~N}$ & $\%$ \\
\hline $\begin{array}{l}\text { Insulators } \\
\mathrm{N}=55\end{array}$ & 3 & $\begin{array}{l}14 \\
\text { mean }\end{array}$ & $\begin{array}{r}22 \\
24.6\end{array}$ & 16 & 8 & 14.5 & 26 & 47.3 & 21 & 38.2 \\
\hline $\begin{array}{l}\text { Workers in } \\
\text { asbestos } \\
\text { cement } \\
\text { product }\end{array}$ & & & & & & & & & & \\
\hline $\begin{array}{l}\text { factory } \\
\mathrm{N}=32\end{array}$ & 6 & $\begin{array}{l}4 \\
\text { mean }\end{array}$ & $\begin{array}{r}15 \\
22.3\end{array}$ & 7 & 15 & 46.9 & 10 & 31.3 & 7 & 21.9 \\
\hline $\begin{array}{l}\text { Workers in } \\
\text { asbestos }\end{array}$ & & & & & & & & & & \\
\hline $\begin{array}{l}\text { quarry } \\
\mathrm{N}=29\end{array}$ & 3 & $\begin{array}{l}8 \\
\text { mean }\end{array}$ & $\begin{array}{r}12 \\
21.8\end{array}$ & 6 & 8 & 27.6 & 8 & 27.6 & 13 & 44.8 \\
\hline $\begin{array}{l}\text { Asbestos } \\
\text { sprayers } \\
N=8\end{array}$ & 1 & $\begin{array}{l}6 \\
\text { mean }\end{array}$ & $\begin{array}{r}1 \\
12.8\end{array}$ & 一 & 2 & 25.0 & 3 & 37.5 & 3 & 37.5 \\
\hline $\begin{array}{l}\text { Others } \\
\mathrm{N}=9\end{array}$ & 4 & $\begin{array}{l}3 \\
\text { mean }\end{array}$ & $\begin{array}{r}1 \\
14.8 \\
\end{array}$ & 1 & 1 & 11.1 & 6 & 66.7 & 2 & 22.2 \\
\hline $\begin{array}{l}\text { Total } \\
\mathrm{N}=133\end{array}$ & 17 & $\begin{array}{l}35 \\
\text { mean }\end{array}$ & $\begin{array}{r}51 \\
22.1 \\
\end{array}$ & 30 & 34 & 25.6 & 53 & 39.8 & 46 & 34.6 \\
\hline
\end{tabular}


a pneumotachograph (Medistor ${ }^{\circledR}$, U.S.A.). $\mathrm{FEV}^{\circ} \%$ was calculated as $\left(\mathrm{FEV}_{1.0} / \mathrm{VC}\right) \times$ 100 (5). The single-breath carbon-monoxide transfer factor $\left(\mathrm{T}_{\left.\mathrm{c}_{\mathrm{c}}\right)}\right)$ was measured according to the usual procedure (15). Three subjects refused to participate in the lung function tests.

The clinical examinations were performed by the same physician (M.H.). Each patient was placed in one of the following three categories: (a) smokers, persons who habitually carried cigarettes or cigarette tobacco for their own use, (b) exsmokers, those who had stopped smoking one year earlier or more, (c) nonsmokers, those who did not and had never smoked cigarettes regularly (table 3 ).

The statistical analyses were made with the chi-square test and, in some comparisons when frequencies were low, with Fisher's exact probability test. Student's t-test was also used.

\section{RESULTS}

\section{Radiographic findings}

Radiographs taken at the time of diagnosis were available for only 116 of the 133 asbestosis patients; 66 of these 116 subjects had been exposed to asbestos after the date of diagnosis.

Table 4 shows the profusion of small opacities found in the two sets of radiographs according to occupational groups. The types of small opacities seen in the reexamination were as follows: $s 98(74 \%)$, t $11(8 \%)$, u $1(0.8 \%)$, p $11(8 \%)$, q 3 $(2 \%)$, r $1(0.8 \%)$ and combined $8(6 \%)$. No large opacities were found. The opacities (small irregular or small rounded) were generally of the same type in both sets of radiographs. However, at the time of the reexamination the small opacities were more profuse than they had been earlier (table 4). At the time of diagnosis they were found in the lower zones of all the subjects, in the middle zones in $78 \%$ of the subjects, and in the upper zones of $16 \%$. At the reexamination the corresponding figures were 100,94 and $34 \%$ for the lower, middle and upper zones, respectively. There was no significant difference in the type, profusion or extent of the opacities between workers in different occupations.

The profusion of fibrosis and the length of exposure have been summarized in table 5 .

In the two sets of radiographs poor definition of the diaphragm and/or cardic outline was just as frequent at the time of diagnosis as at the reexamination, and

Table 4. Number of subjects in different occupations classified according to profusion of small opacities at the time of diagnosis and reexamination.

\begin{tabular}{|c|c|c|c|c|c|c|}
\hline \multirow[t]{2}{*}{ Occupation } & \multicolumn{3}{|c|}{ Profusion at time of diagnosis } & \multicolumn{3}{|c|}{ Profusion at reexamination } \\
\hline & $0 / 1-1 / 1$ & $1 / 2-2 / 2$ & $2 / 3-3 / 4$ & $0 / 1-1 / 1$ & $1 / 2-2 / 2$ & $2 / 3-3 / 4$ \\
\hline Insulators & 39 & 11 & 3 & 27 & 19 & 9 \\
\hline $\begin{array}{l}\text { Workers in asbesto } \\
\text { cement product } \\
\text { factory }\end{array}$ & 17 & 5 & 1 & 14 & 11 & 7 \\
\hline $\begin{array}{l}\text { Workers in asbes- } \\
\text { tos quarry }\end{array}$ & 23 & 一 & 一 & 14 & 12 & 3 \\
\hline Asbestos sprayers & 7 & 1 & 一 & 4 & 4 & - \\
\hline Others & 7 & 1 & 1 & 6 & 2 & 1 \\
\hline TotaI & 93 & 18 & 5 & 65 & 48 & 20 \\
\hline Percentage & $\begin{array}{c}93 / 116= \\
80 \%\end{array}$ & $\begin{array}{c}18 / 116= \\
16 \%\end{array}$ & $\begin{array}{c}5 / 116= \\
4.3 \%\end{array}$ & $\begin{array}{c}65 / 133= \\
49 \%\end{array}$ & $\begin{array}{c}48 / 133= \\
36 \%\end{array}$ & $\begin{array}{c}20 / 133= \\
15 \%\end{array}$ \\
\hline
\end{tabular}


Table 5. Percentage distribution of the subjects $(\mathrm{N}=133)$ according to profusion of fibrosis and length of exposure at the time of the reexamination.

\begin{tabular}{lccccr}
\hline Profusion & \multicolumn{5}{c}{ Exposure time (years) } \\
\cline { 2 - 6 } category & $\leq 9$ & $10-19$ & $20-29$ & $\geq 30$ & Total \\
\hline $0 / 1-1 / 1$ & 4 & 17 & 19 & 9 & 49 \\
$1 / 2-2 / 2$ & 4 & 8 & 14 & 10 & 36 \\
$2 / 3-3 / 4$ & 4 & 2 & 5 & 4 & 15 \\
\hline Total & 12 & 27 & 38 & 23 & 100 \\
\hline
\end{tabular}

Table 6. Vital capacity (VC), forced expiratory volume in $1 \mathrm{~s}$ (FEV 1.0$)$, deltaFEV $\%$ and carbon-monoxide transfer factor $\left(\mathrm{T}_{\mathrm{L}_{\mathrm{co}}}\right.$ ) (mean as the percentage of predicted and the standard deviation) of the subjects grouped according to smoking habits and profusion of small radiographic opacities.

\begin{tabular}{|c|c|c|c|c|c|c|c|c|c|c|c|c|}
\hline \multirow{3}{*}{$\begin{array}{l}\text { Smoking } \\
\text { habits }\end{array}$} & \multicolumn{3}{|c|}{$\mathrm{VC}$} & \multicolumn{3}{|c|}{$\mathrm{FEV}_{1.0}$} & \multicolumn{3}{|c|}{ deltaFEV $/ 0$} & \multicolumn{3}{|c|}{$\mathrm{T}_{\mathrm{I}_{\mathbf{c o}}}$} \\
\hline & \multicolumn{3}{|c|}{$\begin{array}{l}\text { Profusion category } \\
0 / 1-1 / 2-\end{array}$} & \multicolumn{3}{|c|}{$\begin{array}{l}\text { Profusion category } \\
0 / 1-1 / 2\end{array}$} & \multicolumn{3}{|c|}{$\begin{array}{l}\text { Profusion category } \\
0 / 1-1 / 2\end{array}$} & \multicolumn{3}{|c|}{$\begin{array}{l}\text { Profusion category } \\
0 / 1-1 / 2\end{array}$} \\
\hline & $1 / 1$ & $2 / 2$ & $\geq 2 / 3$ & $1 / 1$ & $2 / 2$ & $\geq 2 / 3$ & $1 / 1$ & $2 / 2$ & $\geq 2 / 3$ & $1 / 1$ & $2 / 2$ & $\geq 2 / 3$ \\
\hline \multicolumn{13}{|l|}{$\begin{array}{l}\text { Non- } \\
\text { smokers }\end{array}$} \\
\hline Mean & 75.9 & 63.2 & 72.0 & 79.4 & 62.8 & 78.8 & +3.4 & -0.6 & -10.0 & 102.9 & 98.1 & 78.7 \\
\hline SD & 16.4 & 13.2 & 8.8 & 18.9 & 17.3 & 11.1 & 8.9 & 15.2 & 15.7 & 17.7 & 26.2 & 18.6 \\
\hline $\mathbf{N}$ & 17 & 13 & 4 & 17 & 13 & 4 & 17 & 13 & 4 & 17 & 13 & 4 \\
\hline \multicolumn{13}{|l|}{$\begin{array}{l}\text { Ex- } \\
\text { smokers }\end{array}$} \\
\hline Mean & 77.9 & 70.5 & 61.7 & 81.6 & 66.3 & 63.6 & +4.4 & -5.0 & +1.1 & 90.1 & 98.3 & 67.7 \\
\hline SD & 18.8 & 15.0 & 8.7 & 19.1 & 21.1 & 15.5 & 5.5 & 14.2 & 17.2 & 17.7 & 21.9 & 11.8 \\
\hline $\mathbf{N}$ & 26 & 17 & 7 & 26 & 17 & 7 & 26 & 17 & 7 & 26 & 17 & 7 \\
\hline \multicolumn{13}{|l|}{ Smokers } \\
\hline Mean & 79.4 & 70.4 & 67.8 & 71.8 & 64.1 & 66.3 & -5.1 & -4.3 & +0.2 & 89.8 & 79.4 & 62.6 \\
\hline SD & 14.1 & 18.7 & 10.5 & 13.7 & 22.7 & 11.8 & 8.7 & 13.9 & 7.8 & 14.1 & 23.0 & 19.3 \\
\hline $\mathbf{N}$ & 19 & 18 & 9 & 19 & 18 & 9 & 19 & & 9 & 19 & 18 & 9 \\
\hline \multicolumn{13}{|l|}{ Total } \\
\hline Mean & 77.8 & 68.5 & 66.5 & 78.0 & 64.5 & 67.9 & +1.2 & -3.5 & -0.0 & 93.5 & 91.2 & 67.6 \\
\hline SD & 16.7 & 15.9 & 9.5 & 17.4 & 20.7 & 13.0 & 7.4 & 14.4 & 12.7 & 16.6 & 23.5 & 16.5 \\
\hline $\mathbf{N}$ & 62 & 48 & 20 & 62 & 48 & 20 & 62 & 48 & 20 & 62 & 48 & 20 \\
\hline
\end{tabular}

there were no significant differences for it with respect to the occupation of the workers.

Pleural thickening was present in 66 of the 116 available radiographs taken at the time of diagnosis $(57 \%)$ and in 88 of the 133 taken at the reexamination $(66 \%)$. In regard to the site, width and extent of the pleural thickenings, no significant differences were found between the two sets of radiographs or between the workers in different occupations.

At the reexamination pleural thickening was recorded bilaterally in 60 cases $(68 \%$ ), in the right lung only in 10 cases, and in the left lung only in 18 cases. The width of the pleural shadow was more than 10 $\mathrm{mm}$ in 56 cases $(64 \%)$ and less than $5 \mathrm{~mm}$ in 23 cases $(26 \%$ ) (width $c$ and $a$ of the classification). In 55 cases $(63 \%)$ the total extent of the thickenings exceeded onehalf of the projection of one lateral chest wall (extent 2 of the classification).

Pleural calcifications were recorded in $41 \%$ of the radiographs taken at the time of diagnosis and in $59 \%$ of those taken at the reexamination. Insulators had relatively fewer calcifications than the sub- 
Table 7. Vital capacity (VC), forced expiratory volume in $1 \mathrm{~s}$ (FEV1.0), delta FEV\% and carbon-monoxide transfer factor $\left(\mathrm{T}_{\mathrm{L}} \mathrm{co}\right.$ ) (mean as the percentage of predicted and the standard deviation) of the subjects grouped according to profusion of small radiographic opacities and occurrence of pleural thickening.

\begin{tabular}{|c|c|c|c|c|c|c|c|c|}
\hline \multirow{2}{*}{$\begin{array}{l}\text { Profusion of } \\
\text { small pulmo- } \\
\text { nary opacities }\end{array}$} & \multicolumn{2}{|c|}{$\mathrm{VC}$} & \multicolumn{2}{|c|}{$\mathrm{FEV}_{1.0}$} & \multicolumn{2}{|c|}{ delta $\mathrm{FEV}^{0} \%$} & \multicolumn{2}{|c|}{$\mathrm{T}_{\mathrm{L}_{\mathrm{c} 0}}$} \\
\hline & \multicolumn{2}{|c|}{ Pleural thickening } & \multicolumn{2}{|c|}{ Pleural thickening } & Pleural thickening & hickening & \multicolumn{2}{|c|}{ Pleural thickening } \\
\hline \multicolumn{9}{|l|}{$0 / 1,1 / 0,1 / 1$} \\
\hline Mean & 72.7 & 85.2 & 73.0 & 85.3 & +2.0 & -0.1 & 95.1 & 99.3 \\
\hline SD & 13.2 & 18.4 & 15.3 & 18.8 & 10.0 & 9.8 & 16.5 & 18.6 \\
\hline $\mathrm{N}$ & 34 & 28 & 34 & 38 & 34 & 28 & 34 & 28 \\
\hline \multicolumn{9}{|l|}{$1 / 2,2 / 1,2 / 2$} \\
\hline Mean & 67.6 & 71.4 & 64.4 & 65.3 & -3.6 & -3.3 & 94.2 & 80.0 \\
\hline $\mathrm{SD}$ & 15.0 & 19.7 & 20.3 & 21.9 & 14.0 & 15.3 & 23.4 & 26.7 \\
\hline $\mathbf{N}$ & 35 & 13 & 35 & 13 & 35 & 13 & 35 & 13 \\
\hline \multicolumn{9}{|l|}{$2 / 3$ or more } \\
\hline Mean & 66.3 & 68.5 & 66.1 & 84.0 & +0.1 & -11.0 & 65.7 & 78.0 \\
\hline SD & 10.3 & 7.8 & 12.8 & 14.1 & 11.8 & 24.0 & 15.6 & 31.1 \\
\hline $\mathrm{N}$ & 18 & 2 & 18 & 2 & 18 & 2 & 18 & 2 \\
\hline
\end{tabular}

jects with other occupations $\left(\chi^{2}=7.43\right.$; $\mathrm{p}<0.01$ ).

There was no significant difference for the occurrence of other diseases (additional symbols of the ILO U/C classification) between the time of diagnosis and the reexamination or between the different occupations. Of the 133 patients who were reexamined, $41(31 \%)$ had an enlarged left ventricle, $19(14 \%)$ showed signs of emphysema, and $22(17 \%)$ honeycombing.

\section{Respiratory physiological measurements}

Among the 130 patients who participated in the respiratory physiological measurements in the reexamination, VC was normal $(\geq 80 \%)$ in $47(36 \%)$ and decreased $(<80 \%)$ in $83(64 \%)$. FEV Fi. $_{10}$ was normal in 44 subjects $(34 \%)$ and decreased $(<80 \%)$ in $86(66 \%)$. For 13 patients $(10 \%)$ the delta FEV\% (predicted minus observed) was greater than or equal to $13 \%$. $\mathrm{T}_{\mathrm{L}_{00}}$ was decreased $(<80 \%)$ in 46 subjects $(35 \%)$.

The patients were grouped according to smoking habits, profusion of small radiographic opacities, VC, $\mathrm{FEV}_{1.0}$, and $\mathrm{FEV} \%$ (table 6). In addition to opacities the presence of pleural thickening was evaluated, and the various groups were compared with respect to pleural changes and respiratory function.
The more severe the fibrosis, the greater, as a rule, the decrease in $\mathrm{VC}$ and $\mathrm{FEV}_{1.0}$. $\mathrm{TL}_{\mathrm{c} 0}$, on the contrary, was generally impaired only in advanced cases (fibrosis $2 / 3$ or more) (table 6).

Obstruction was rarely observed among the patients $(10 \%)$.

No significant differences in VC were found between the groups with different smoking habits. However the $\mathrm{FEV}_{1.0}$ of exsmokers was somewhat higher than that of smokers $(t=1.86 ; p<0.07)$ among the patients with the mildest lung fibrosis (less than 1/2). But the subjects with moderate and severe lung fibrosis showed no differences in $\mathrm{FEV}_{1.0}$ according to smoking habits (table 6).

In delta $\mathrm{FEV}^{0} \%$ there was likewise no difference according to smoking habits among the subjects with severe and moderate lung fibrosis, but in the group with mild fibrosis smokers showed signs of obstruction more often than nonsmokers $(t=2.65 ; p<0.05)$ and exsmokers $(t=$ 4.44; p < 0.001) (table 6).

Neither did the last lung function parameter to be assessed, $\mathrm{TL}_{\mathrm{co}}$, significantly differ according to smoking habits among the patients with severe fibrosis. But in the group with moderate fibrosis, smokers showed signs of impaired diffusion when compared with exsmokers $(\mathrm{t}=2.42 ; \mathrm{p}<0.05)$ and nonsmokers $(\mathrm{t}=$ $1.91 ; \mathrm{p}<0.07$ ) (table 6). Furthermore, in 
the group with mild fibrosis the $\mathrm{TL}_{\mathrm{co}}$ values were lower for smokers than for nonsmokers $(t=2.26 ; p<0.05)$, and lower for exsmokers than for nonsmokers $(t=2.11$; $\mathrm{p}<0.05$ ) (table 7).

The VC, $\mathrm{FEV}_{1.0}$, delta $\mathrm{FEV} \%$ and $\mathrm{TL}_{\mathrm{co}}$ in the 130 patients tested at the reexamination are presented in table 7 according to the profusion of small opacities and the presence of pleural thickening. In the group with mild fibrosis, $\mathrm{VC}$ and $\mathrm{FEV}_{1.0}$ were significantly lower in the patients with pleural thickening than in those without $(p<0.01$; for $V C t=3.02$, for $\mathrm{FEV}_{1.0} \mathrm{t}=2.72$ ).

No association could be shown between pleural calcifications and functional impairment.

\section{DISCUSSION}

Asbestos-related diseases have been studied in Finland since 1947 (19). In 1960 Kiviluoto published an extensive radiographic investigation on the occurrence of pleural calcifications among people living in the vicinity of two asbestos mines in Finland. He showed that bilateral calcifications of the parietal pleura were common (11). There is a certain discrepancy between this finding and the results of the first Finnish study (19), in which no case of pleural calcification was detected. The formation of calcareous plaques seems to require a very long time, since lesions are seldom observed in patients under 30 years of age (13).

The occurrence of unusual pleural calcifications in compulsory mass radiographs in Finland was studied by Raunio (16). Since early pleural changes are difficult to detect radiologically, other methods have also been tried, e.g., ultrasonic studies (20).

The diagnostic criteria of asbestosis have been the subject of much debate (14). In the present study widely accepted diagnostic criteria were used (4). Some authors (8) have advocated more rigorous criteria however. A person with an occu- pational history of exposure to asbestos dust and interstitial lung fibrosis does not necessarily have asbestosis. Doubt could particularly be cast on cases with a relatively slight exposure and fibrosis classified as $0 / 1$. Additional diagnostic criteria do not afford an absolutely certain diagnosis but would increase its probability.

Of the 54 patients in whom lung fibrosis was classed as grade $0 / 1$ at the time of diagnosis in the present study, 37 had moved to a higher grade in the follow-up. The clear progression of the condition supports the diagnosis. In the remaining 17 patients, the apparent quiescence of the fibrosis can probably, in many cases, be attributed to the short interval between the time of diagnosis and the follow-up.

The asbestosis of the quarry workers in the study appeared to be certified earlier than that of the other occupational groups (table 4). This phenomonen can probably be attributed to the fact that these subjects have been more carefully checked than the others, as they have attended periodic health examinations at our Institute.

The quality of asbestos varied in different occupations. Asbestos sprayers were exposed to crocidolite, and asbestos quarry workers to anthophyllite. In other occupations the asbestos exposure was mixed, consisting mainly of chrysotile and, in smaller amounts, anthophyllite, crocidolite and amosite. The quality of asbestos according to occupation had no significant effect on the radiographic findings of the asbestos patients.

If a person has been exposed to asbestos dust and has interstitial lung fibrosis (and other signs of disease), there is no test that will rule out asbestosis, even if there is evidence for some other disease that produces similar signs. Fibrosing alveolitis, although a rare condition, should be borne in mind, since it produces a similar picture (18).

In the analysis of the radiographs the sole criterion for such qualities as "irregular" or "rounded," as well as for profusion, was the similarity to the reference films of the ILO U/C classification $(10,12)$. The fact that a clear progression was found for lung fibrosis but not for pleural thickening may be due to the difference in scale. For the profusion of lung opacities there are 
10 grades from the slightest to the most advanced changes, whereas for the width and extent of pleural thickening there are only three grades.

Vital capacity has rather generally been considered to be a good measure of asbestosis. Evidence has been published suggesting that it may even be reduced before there is radiological evidence of disease (3).

Different opinions have been presented concerning the value of the gas transfer factor in the diagnosis of asbestosis. According to Britton et al. (7), a marked reduction in the transfer factor often precedes any significant decline in vital capacity. In their series changes in vital capacity and the transfer factor did not give any indication of prognosis. In a study by Woitowitz (22), vital capacity decreased significantly as asbestos exposure increased; it was concluded that a decrease in vital capacity could be used as a sign of early asbestosis, even prior to any radiographic abnormality. Measurements of FEV\% did not support the view that the obstructive changes were due to asbestosis. No impairment in alveolar gas exchange was found. According to Woitowitz tests of the pulmonary gas transfer factor (diffusion capacity) do not aid the early detection of asbestosis, and this conclusion was supported by the present results. Since histologically some anatomical obstacle to gas exchange must be assumed to exist, it can be assumed that pulmonary functional reserves compensate for the deficit.

Pulmonary fibrosis is thought to be accompanied by a greater degree of functional abnormality than pleural changes. The present study supports this assumption.

\section{REFERENCES}

1. BADER, M. E., BADER, R. A. and SELIKOFF, I. Pulmonary function in asbestosis of the lung, an alveolar capillary block syndrome. Am. j. med. 30 (1961) 235-242.

2. BADER, M. E., BADER, R. A., TIERSTEIN, A. S, MILLER, A. and SELIKOFF, I. J. Pulmonary function and radiographic changes in 598 workers with varying duration of exposure to asbestos. $M$ t. sinai $j$. med. 37 (1970) 492-500.
3. BECKLAKE, M. Lung function. In: Biological effects of asbestos. International Agency for Research on Cancer, Lyon 1973, pp. $31-39$.

4. BECKLAKE, M. Asbestos-related diseases of the lung and other organs: Their epidemiology and implications for clinical practice. Am. rev. respir. dis. 114 (1976) 187227.

5. BERGLUND, E., BIRATH, G., BJURE, J., GRIMBY, G., KJELLMER, J., SANDQVIST, L. and SÖDERHOLM, B. Spirometric studies in normal subjects: I. Forced expirograms in subjects between 7 and 70 years of age. Acta med. scand. 173 (1963) 185.

6. BOHLIG, H. and GILSON, J. C. Radiology. In: Biological ejfects of asbestos. International Agency for Research on Cancer, Lyon 1973, pp. 25-30.

7. BRITTON, M. G., HUGHES, D. T. D. and WEAVER, A. M. J. Serial pulmonary function tests in patients with asbestosis. Thorax 32 (1977): 1, 45-52.

8. EVANS, C. C., LEWINSÖHN, H. C. and EVANS, J. M. Frequency of HLA antigens in asbestos workers with and without pulmonary fibrosis. Br. med. j. 1 (1977) $603-605$.

9. FLETCHER, D. E. and EDGE, J. R. The early radiological changes in pulmonary and pleural asbestosis. Clin. radiol. 21 (1970) $355-365$.

10. INTERNATIONAL LABOR OFFICE. ILO $U / C$ international classification of pneumoconioses (Occupational safety and health series 22 (rev.)). Geneva 1972. 32 p.

11. KIVILUOTO, E. Pleural calcification as a roentgenologic sign of non occupational endemic anthophyllite asbestosis. Acta radiol. (1960): suppl. 194, 1-67.

12. LIDDEL, F. D. K. Radiological assessment of small pneumoconiotic opacities. $\mathrm{Br} . j$. ind. med. 34 (1977): 2, 85-94.

13. MEURMAN, L. Asbestos bodies and pleuraI plaques in a Finnish series of autopsy cases. Acta pathol. microbiol. scand. (1966): suppl. 181, 1-107.

14. PARKES, W. R. Asbestos-related disorders. Br. j. dis. chest 67 (1973) 261-300.

15. PYÓRÄLÄ, K., HEINONEN, A. O. and KARVONEN, M. J. Pulmonary function in former endurance athletes. Acta med. scand. 183 (1968) 263-273.

16. RAUNIO, V. Occurrence of unusual pleural calcifications in Finland: Studies on atmospheric pollution caused by asbestos. Ann. med. intern. fenn. 55 (1966): suppl. 47, $1-61$.

17. REGAN, G. M., TAGG, B., WALFORD, J. and THOMSON, M. L. The relative importance of clinical, radiological and pulmonary function variables in evaluating asbestosis and chronic obstructive airway disease in asbestos workers. Clin. sci. 41 (1971) 569-582.

18. TURNER-WARWICK, M. A perspective view on widespread pulmonary fibrosis. Br. med. j. 2 (1974) 371-376. 
19. WEGELIUS, $C$. Changes in the lungs in 126 cases of asbestosis abserved in Finland. Acta radiol. 23 (1947) 139-152.

20. WIIKERI, M., JÄÄSKELÄINEN, J. and TÄHTI, E. UItrasonic examination of pleural thickenings and calcifications in occupational asbestosis. Dis. chest 54 (1968) 1720.

Received for publication: 4 July 1978
21. WILLIAMS, R. and HUGH-JONES, P. The significance of lung function changes in asbestosis. Thorax 15 (1960) 109-119.

22. WOITOWITZ, H.-J. Pulmonary function in workers exposed to asbestos: Results of epidemiological studies in Federal Republic Germany. Hefte Unfallheilkd. 126 (1976). $598-603$. 